(A.I. at $24 \mathrm{~h}$ intervals $-3.10^{9}$ or $6.10^{9} \mathrm{spz} / \mathrm{Al}$ ). A total of $93.6 \mathrm{p} .100$ of the females exhibited oestrus between day 5 and day 8 after the treatment. The presence of the boar in the piggery during and after progestogen intake, significantly improved the heat synchronization (p. 100 of oestrus on day 5-day 8:97.4 p. 100 - absence of boar in the building: 85.7 p. 100). On an average, females of the LW type returned to oestrus later $(90.6 \mathrm{p}$. 100) than LR $(100 \mathrm{p} .100)$ and crossbreds $(94$ p. 100). Insemination on predetermined days was possible in crossbred and LR females. Farrowing rate and litter size (piglets born alive) were similar whatever the mode of fertilization (crossbred, I : 75.7 p. $100,9.5 ;$ II : 78.3 p. $100 ; 9.2$ - LR, I : 94.1 p. $100,10.2 ;$ II : 83.3 p. $100,9.6)$. Results were similar in LW females (I : 51.3 p. 100 , $9.0 ;$ II $: 78.3$ p. $100,9.2)$. Increase in the number of spermatozoa used $\left(6.10^{*}\right.$ instead of $3.10^{9}$ ) did not alter either the farrowing rate or the litter size. Between and within herd variations in fertility and prolificacy were large. However, in $30 \mathrm{p} .100$ of the herds, inseminating on predetermined days or after detected oestrus did not affect the farrowing results.

After drying-off, a short administration of Regumate to primiparous females (3 days - $20 \mathrm{mg} / \mathrm{d}$ - treatment started the day of drying off - double A.I. after oestrus detection (3.109 spz/A.I.) had a beneficial effect on oestrus synchronization (D4-D8) (controls, $\mathrm{n}=72 \mathrm{I}: 72.2 \mathrm{p} .100$; treated, $\mathrm{n}=91 ; \mathrm{II}: 83.5 \mathrm{p} .100$ ), farrowing rate (I : $66.7 \mathrm{p} .100$; II : 82.4 p. 100 ) and prolificacy (I : $9.8 \pm 2.9$, II : $10.5 \pm 3.2$ ). In multiparous sows, the progestogen treatment did no improve the good results observed in the controls after the end of lactation.

\title{
Application of artificial insemination in pigs by the farmer or the inseminator \\ Technical and practical results as well as advantage of the method
}

\author{
F. BARITEAU *, J. BUSSIERE *, M. COUROT **, M. PAQUIGNON*** \\ *I.N.R.A., Station Expérimentale d'Insémination artificielle, 86480 Rouille \\ ** Station de Physiologie de la Reproduction, Nouzilly, 37380 Monnaie \\ **: I.T.P., 149, rue de Bercy, 75595 Paris Cedex 12 \\ France
}

This report deals with the analysis of fertility rates obtained after application of A.I. in pigs either by farmers or by inseminators for a period of four years.

The farrowing rate calculated from all available results, was 72.4 and 70.5 p. 100 respectively for the farmer and the inseminator group. The prolificacy ( 10.4 piglets) did not vary from one group to the other.

When A.I. was practised by the farmer, differences occurred depending on the age of the semen. Accordingly, the role played by the semen storage conditions is very important. The utilization of a double dose or not on Day 2 did not seem to affect the fertility. Well trained inseminators as well as use of sows with a weaning oestrus interval shorter than 9 days led to a higher fertility. Semen diluted with the Guelph extender could be used up to 3 days after collection without causing any lowering of fertility.

In the best conditions, fertility and prolificacy were similar to those resulting from natural mating. Utilization of boars from an A.I. centre provided an excellent genetic guarantee. 